\title{
Correction to: On the Existence of Schur-like Forms for Matrices with Symmetry Structures
}

\author{
Christian Mehl $^{1}$ \\ Published online: 19 July 2021 \\ (C) The Author(s) 2021
}

\section{Correction to: Vietnam Journal of Mathematics (2020) 48:831-845 https://doi.org/10.1007/s10013-020-00394-3}

The article "On the Existence of Schur-like Forms for Matrices with Symmetry Structures", written by Christian Mehl, was originally published Online First without Open Access. After publication in volume 48, issue 4, page 831-845 the author decided to opt for Open Choice and to make the article Open Access publication. Therefore, the copyright of the article has been changed to (CThe Author(s) 2020 and the article is forthwith distributed under the terms of the Creative Commons Attribution 4.0. International License, which permits use, sharing, adaptation, distribution and reproduction in any medium or format, as long as you give appropriate credit to the original author(s) and the source, provide a link to the Creative Commons licence, and indicate if changes were made. The images or other third party material in this article are included in the article's Creative Commons licence, unless indicated otherwise in a credit line to the material. If material is not included in the article's Creative Commons licence and your intended use is not permitted by statutory regulation or exceeds the permitted use, you will need to obtain permission directly from the copyright holder. To view a copy of this licence, visit http://creativecommons.org/licenses/by/4.0. Open Access funding enabled and organized by Projekt DEAL.

Open Access This article is licensed under a Creative Commons Attribution 4.0 International License, which permits use, sharing, adaptation, distribution and reproduction in any medium or format, as long as you give appropriate credit to the original author(s) and the source, provide a link to the Creative Commons licence, and

The online version of the original article can be found at https://oi.org/10.1007/s10013-020-00394-3

Christian Mehl

mehl@math.tu-berlin.de

1 Institut für Mathematik, Technische Universität Berlin, MA 4-5, 10623 Berlin, Germany 
indicate if changes were made. The images or other third party material in this article are included in the article's Creative Commons licence, unless indicated otherwise in a credit line to the material. If material is not included in the article's Creative Commons licence and your intended use is not permitted by statutory regulation or exceeds the permitted use, you will need to obtain permission directly from the copyright holder. To view a copy of this licence, visit http://creativecommons.org/licenses/by/4.0/.

Publisher's Note Springer Nature remains neutral with regard to jurisdictional claims in published maps and institutional affiliations. 